\title{
The Nutritional Contributions of Moringa oleifera (Lam) and Prosopis africana (Guill \& Perr) Taub Seeds for Sustainable Diets to Food Security
}

\author{
*Abubakar, E.M. ${ }^{1}$, Abdulhamid, B. ${ }^{2}$ \\ ${ }^{l}$ Department of Forestry Technology, College of Agriculture, Yelwa, Bauchi State-Nigeria \\ ${ }^{2}$ Department of Forestry Technology, Audu Bako College of Agriculture, Dambatta, Kano State-Nigeria
}

*Corresponding Author: Abubakar, E.M., Department of Forestry Technology, College of Agriculture, Yelwa, Bauchi State- Nigeria.

\begin{abstract}
The objectives of this study were to investigate the nutritive contents of M. oleifera and P. africana seeds in Northern region of Nigeria. The seeds were analyzed in water-soluble forms to determine their mineral (calcium, phosphorus, potassium, iron, magnesium and iodine) and vitamin ( $A, C$ and E) compositions in order to encourage the possibility of using these seeds for human consumption due to malnutrition in the under developed countries. Atomic Absorption Spectrophotometer and Titration method showed that the seeds were found to be good sources of minerals and vitamins. Based on the results obtained, potassium, magnesium and iodine contents were high in $P$. africana seeds $(1369.30 \pm 1.00,438.50 \pm 0.20$ and $102.50 \pm 0.20 \mathrm{mg} / 100 \mathrm{~g})$ than from M. oleifera seeds $(502.00 \pm 1.00 \mathrm{mg} / 100 \mathrm{~g}, 218.20 \pm 0.10$ and59.05 \pm 0.03 $\mathrm{mg} / 100 \mathrm{~g})$. But, calcium and iron were higher in M. oleifera $(245.73 \pm 0.13$ and $37.08 \pm 0.05 \mathrm{mg} / 100 \mathrm{~g})$ than from P. africana $(101.60 \pm 0.26$ and $37.08 \pm 0.05 \mathrm{mg} / 100 \mathrm{~g})$ seeds, respectively. Vitamins $A, C$ and $E$ evaluated from the seeds were found to be higher in M. oleifera seeds $(6.66 \pm 0.01,214.50 \pm 6.50$ and $2801.50 \pm 1.50 \mathrm{mg} / 100 \mathrm{~g})$ than from $P$. africana seeds $(0.07 \pm 0.06,46.90 \pm 1.60$ and $51.15 \pm 0.15 \mathrm{mg} / 100 \mathrm{~g})$. The seeds are very good sources of nutrients for human body as useful dietary supplements, also contain essential vitamins for human good health. The result of this study shows that Moringa and Prosopis seeds can contribute useful amounts of essential nutrients to the diet of man. Thus, the present of nitrite, total acidity and other anti-nutrients should be study to make the seeds safe for consumption.
\end{abstract}

Keywords: Forest; Nutrients; Minerals; Seeds and Vitamins.

\section{INTRODUCTION}

Measure is being taken to boost food production by conventional agriculture. A lot of interest is currently being focused on the possibilities of exploiting the vast numbers of less familiar plant resources existing in the wild (Felger et al., 1979). Many such plants have been identified, but the lack of data on their nutritive contents has limited the prospects for their utilization (Viano et al., 1995). The consequences of malnutrition in the developing countries like Nigeria cannot be over emphasize, this tragedy is mostly found in the rural areas. It can be attributed to mere ignorance of food trees around them. The wild seeds rich in nutrients could effectively reduce the rate of malnutrition among the rural and urban communities. These wild seeds could be good nutrient sources if integrated fully into human nutrition.

\subsection{Nutritive Values of Moringa oleifera Seed}

M. oleifera is the sole genus in the flowering plant family Moringaceae. Order of Brassicales, genus moringa and specie oleifera (Lam). Thirteen (13) varieties/species are known with oleifera (Verdcourt, 1985). The generic names is derived from the Tamil word "Murunggai"or the Malayalam word "Moringa" both of which refer to Moringa oleifera. The most widely known specie is Moringa oleifera a multi-purpose tree, native to the foothills of the Himalayas in North-western Indian and Pakistan (Von Maydell, 1986). It is cultivated throughout the tropics for human food, livestock forage, medicine, dye and water purification (Folkard and Sutherland, 1996). Iit is known by several names in different countries, but is popularly called the "drumstick tree" for its pods that are used by drummers; The "Horseradish tree" for the flavor of its roots; The "miracle tree" for the multi-purpose uses, (Von Maydell, 1986), with vernacular name as Zogale in Hausa. 
Growing $M$. oleifera is like growing multi-vitamins at your doorstep. The disease- preventing nutrients including: calcium, iron, phosphorus and vitamin A, B \& C. They even contain all of the essential amino acids, which are unusual for a plant source (www.treesforlife.org/moringa/book, 2005). It is grown in many parts of the world, with the fruits being used for food ( $\mathrm{Lu}$ and Olson 2001). The unripe pods (seeds) act as a preventive against intestinal worms, the fruit is sweet and pungent in taste, an appetizer preventing eye disorders and increasing semen both qualitatively and quantitatively. In medicines, these drumstick seeds are used as a sexual virility drug for treating erectile dysfunction in men and also in women for prolonging sexual activity (Lea, 2010). The Moringa seeds yield 38-40\% edible oil (called ben oil from the high concentration of behinic acid contained in the oil).

\subsection{Nutritive Values of Prosopis africana Seed}

P. africana belongs to the family Fabaceae and sub family Mimosoideae. It is a savannah tree, 12.2$18.3 \mathrm{~m}$ (40-60 feet) height and up to $2.1 \mathrm{~m}$ (7 feet) in diameter. The trees of $P$. africana can be found growing wild in northern (especially middle belt), eastern and southern parts of Nigeria (Balogun and Oyeyiola, 2012). Prosopis (mesquite) is a genus of about 45 species of leguminous spiny pod-bearing trees and shrubs found in subtropical and tropical regions of America, Africa and southwest Asia (Anon, 2009). The indehiscent seeds (pods) are palatable to man and animals (Aremu et al., 2006). The seeds are fermented into a traditional condiment, called okpehe which can serve as a low-cost source of protein especially for the rural populace.

According to Balogun and Oyeyiola, (2012), P. africana seed has an important role to play in improving the nutritional quality of the traditional diets of Nigerians which often lack variety and consist of large quantities of staple food (cassava, yam, maize) with supplements of plantain, cocoyam, rice and beans depending on availability and season. The staple foods provide the calories but are poor in other nutrients such as minerals and vitamins. The low protein and minerals in these diets contributes to low nutrition security of the people (Balogun and Oyeyiola, 2012). The Nigerian diets can be improved by complementing the staples with soups that are rich sources of protein and minerals. Okpehe can be used as a condiment in the preparation of such soups so as to enrich its nutrient content. It is one of the lesser-known legume seed crops used as food condiment that can serve as a substitute for meat for low-income earners and can reduce protein-calorie malnutrition and essential fatty acid.

Most wild tree seeds or fruits are better source of minerals, protein and vitamins. For instance, the value of calcium $(208 \mathrm{mg} / \mathrm{kg}$ ) in Afzelia africana seed was found to be higher than those of quinoa (86 $\mathrm{mg} / \mathrm{kg}$ ), African nutmeg (203.7 mg/kg) (Ogungbenle et al, 2005). Calcium accounts for about $75 \%$ of the weight of the mineral element present in the body. The deficiency of calcium can also affect the life of newly born baby where the body and the bone is very soft and this becomes hardened as the calcium intake increases. So the diet must supply a high amount of calcium for proper functions of the body; calcium is the principal contributor to bone formation (Fleck, 1976).

The objective of this study is to evaluate the nutritive values of $M$. oleifera and $P$. african seeds, so as to encourage their uses and inclusion in human food in order to effectively reduce the level of malnutrition in the under developed countries. These wild seeds could be good nutrient sources if integrated fully into human and animal nutrition. In this regard, attention should be drawn to cheap sources of minerals and vitamins like M. oleifera and P. africana, among other leguminous plants, which could reduce the rate of nutrition deficiency.

\section{MATERIALS AND METHODS}

\subsection{Study Area}

The study covered the eighteen Northern states of Nigeria where the selected seeds are available and use. Seeds evaluation was conducted in Food Biochemistry laboratory of the department of Food Science Technology, University of Agriculture Makurdi (UAM), located on longitude $8^{\circ} 33 \mathrm{~N}$, latitude $7^{\circ} 44 \mathrm{E}$ in Benue State which lies in the middle belt of Nigeria. Characterized by two distinct seasonsDry and Wet in the Southern guinea savannah. The climate of the area is tropical sub-humid climate with high temperatures, high humidity, the average maximum and minimum daily temperature of $35^{\circ}$ and $21^{\circ} \mathrm{C}$ in wet season, $37 \mathrm{C}$ and $16^{\circ} \mathrm{C}$ in dry season respectively. The mean annual rainfall value is $1200 \mathrm{~mm}$ to $1500 \mathrm{~mm}$. The vegetation of the area has been described as guinea savannah. 


\subsection{Sample Preparation and Analysis}

Matured seeds were obtained from different forests within the region and stored in a polythene bags to prevent moisture loss and possible contamination during transportation to the laboratory. The samples were identified at the forestry general laboratory, University of Agriculture Makurdi. The samples were prepared and used for minerals and vitamins analysis by washing with distilled water to remove all impurities and dried at room temperature to remove residual moisture. The samples were oven dried at $55^{\circ} \mathrm{C}$ for $24 \mathrm{~h}$. The dried seeds were grounded into powder using a mortar and pestle and then sieved through 20 inch mesh sieves and analyzed using the standard procedures of AOAC (1990). All analyses were done in triplicates. The minerals and vitamins of the selected seeds were determined using the standard procedures of AOAC (2005). Analytical reagent nitric acid, hydrochloric acid and standard iron solution were used.

\subsection{Determination of Mineral and Vitamin Contents}

The mineral contents of samples were determined using Atomic Absorption Spectrophotometer, according to the procedure described by Allen et al., (1984). One gram of each samples was digested by wet-digestion method using combination of percholic acid, nitric acid and sulphuric acid mixture (Pearson 1973) in the ratio 8:2:1, respectively, and filtered. The digest obtained was used for the various analyses. De-ionized water was used to avoid interferences from the minerals that may be contained in the water. The filtrate was made up to mark in a $5 \mathrm{ml}$ volumetric flask. The filtered solution was loaded to an Atomic Absorption Spectrophotometer. The standard curve for each mineral was prepared from known standards and the mineral value of samples estimated against that of the standard curve. All the mineral elements were determined on spectrophotometer using the filter corresponding to each mineral element.

Vitamins $\mathrm{A}, \mathrm{C}$ and $\mathrm{E}$ were analyzed in juices formed on $5 \mathrm{~g}$ sample and determined by filtration method described by Pearson (1973) using Whatman filter paper. The filtrate was titrated hot (80$90^{\circ} \mathrm{C}$ ) that persists for 30 seconds (using Titration method).

\subsection{Statistical Analysis of Data}

Data generated from all analyses were subjected to statistical analysis using SPSS version21.0 through one way analysis of variance (ANOVA). Significant difference between samples was tested at $\mathrm{P}=0.05$ using $\mathrm{LSD}$.

\section{RESULTS AND DISCUSSION}

Table 1 shows vitamins contents evaluated from the forest edible seeds, based on the results $M$. oleifera seeds had higher content of vitamins A, C and E $(6.66 \pm 0.01,214.50 \pm 6.50$ and $2801.50 \pm$ $1.50 \mathrm{mg} / 100 \mathrm{~g})$ than $P$. africana seeds which content vitamins A, C and E $(0.07 \pm 0.06,46.90 \pm 1.60$ and $51.15 \pm 0.15 \mathrm{mg} / 100 \mathrm{~g}$ ), respectively. The ANOVA result on vitamins content of the forest seeds showed significantly different $(\mathrm{p}<0.05)$ between the study seeds. Vitamin A was significantly $(\mathrm{p}=0.041)$ higher in M. oleifera seeds than $P$. africana seeds. Also, m. oleifera seeds content high vitamin $\mathrm{C}$ than $P$. africana seeds with significant variation at $\mathrm{p}=0.007$ levels.

Table 1. Vitamin Composition in M. oleifera and P. africana Seeds from the Study Area

\begin{tabular}{|l|l|l|l|}
\hline Tree specie & Vitamins (mg/100 g) & \multicolumn{1}{|c|}{ C } & \multicolumn{1}{|c|}{ E } \\
\hline & \multicolumn{1}{|c|}{ A } & \multicolumn{1}{|c|}{ C } & $2801.50 \pm 1.50 \mathrm{~ns}$ \\
\hline Moringa oleifera & $6.66 \pm 0.01^{*}$ & $46.90 \pm 1.60^{*}$ & $51.15 \pm 0.15 \mathrm{~ns}$ \\
\hline Prosopis africana & $0.07 \pm 0.06^{*}$ & 0.007 & 0.020 \\
\hline LSD & 0.041 & $0.50^{*}$ & \\
\hline
\end{tabular}

Means on the same column with superscript differ significantly $(P<0.05) ; n s=$ Not significantly different

Table 2, shows the mineral contents of the study edible forest seeds. ANOVA results showed variation significantly $(\mathrm{P}<0.05)$ on the mineral compositions from the forest seeds. The calcium content from the study seeds ranged from $101.60 \pm 0.26 \mathrm{mg} / 100 \mathrm{~g}$ (P. africana) to $245.73 \pm 0.13$ $\mathrm{mg} / 100 \mathrm{~g}$ (M. oleifera seeds). Potassium, magnesium and iodine contents were high in $P$. africana seeds $(1369.30 \pm 1.00,438.50 \pm 0.20$ and $102.50 \pm 0.20 \mathrm{mg} / 100 \mathrm{~g})$ than from M. oleifera seeds $(502.00 \pm 1.00 \mathrm{mg} / 100 \mathrm{~g}, 218.20 \pm 0.10$ and $59.05 \pm 0.03 \mathrm{mg} / 100 \mathrm{~g})$ respectively. While, calcium and iron were found higher in $M$. oleifera seeds $(245.73 \pm 0.13$ and $37.08 \pm 0.05 \mathrm{mg} / 100 \mathrm{~g})$ than from $P$. africana $(101.60 \pm 0.26$ and $37.08 \pm 0.05 \mathrm{mg} / 100 \mathrm{~g})$ seeds, respectively. 
The Nutritional Contributions of Moringa oleifera (Lam) and Prosopis africana (Guill \& Perr) Taub Seeds for Sustainable Diets to Food Security

Table 2. Mineral Elements Composition of M. oleifera and P. africana Seeds from the Study Area

\begin{tabular}{|c|c|c|c|c|c|c|}
\hline \multicolumn{3}{|c|}{ Tree species } & \multicolumn{3}{|c|}{ Minerals (mg/100 g) } & \\
\hline & $\mathbf{C a}$ & $\mathbf{K}$ & $\mathbf{F e}$ & $\mathbf{P}$ & Mg & I \\
\hline $\begin{array}{l}\text { M. } \\
\text { oleifera }\end{array}$ & $245.73 \pm 0.13^{*}$ & $502.00 \pm 1.00 *$ & $37.08 \pm 0.05^{*}$ & $\begin{array}{ll}468.00 & \pm \\
1.00 * & \end{array}$ & $218.20 \pm 0.10^{*}$ & $59.05 \pm 0.03 *$ \\
\hline $\begin{array}{l}P . \\
\text { africana }\end{array}$ & $101.60 \pm 0.26^{*}$ & $\begin{array}{l}1369.30 \\
\pm 1.00^{*}\end{array}$ & $26.06 \pm 0.04 *$ & $201.50 \pm 0.20 *$ & $438.50 \pm 0.20 *$ & $102.50 \pm 0.20 *$ \\
\hline
\end{tabular}

*= Significantly different at $p<0.05$ within column

Where: $\mathrm{Ca}=$ calcium, $\mathrm{K}=$ potassium, $\mathrm{Fe}=$ iron, $P=$ phosphorus, $\mathrm{Mg}=$ magnesium and $\mathrm{I}=$ iodine

This finding (Table 1), M. oleifera seed had higher content of vitamin E. This seed contain essential nutrients for human good health and is important food seeds. It is therefore a very dietary source of vitamins $\mathrm{A}$ and $\mathrm{C}$ for human body; also it would serve as useful dietary supplements. The vitamin A, $\mathrm{C}$ and $\mathrm{E}$ contents from these seeds are adequate to supplement other dietary sources. Vitamin $\mathrm{A}$ is a good treatment for people suffering from eye problem while deficiency of vitamin C leads to scurvy and gingivitis (Agatemor and Mark, 2006).

The calcium contents of $P$. africana seeds was found to be lower $(101.60 \pm 0.26 \mathrm{mg} / 100 \mathrm{~g})$ than $M$. oleifera seeds $(245.73 \pm 0.13)$ (Table 1$)$. These values are very high when compared to $2.17 \mathrm{mg} / 100 \mathrm{~g}$ obtained from cocoa bean (Olaefe, 1987), but low when compared to $900 \mathrm{mg} / 100 \mathrm{~g}$ obtained for Benni seed (Dashak, and Fali, 1993). The dietary allowance for calcium is $800 \mathrm{mg}$ for $70 \mathrm{~kg}$ man (National Research Council, 1989). This shows that moringa and prosopis seeds can supplement other sources of dietary calcium (Agatemor and Mark, 2006). Calcium, an important mineral require for bone formation and neurological function. Calcium deficiency in children leads to rickets, while in adults it may results in osteomalacia. As rickets is a common problem in the Africa, calcium intake is especially important for children who live in this part of Africa (Scariano et al., 1995).

The Potassium contents of $M$. oleifera and $P$. africana seeds differed significantly $(\mathrm{P}<0.05)$. High potassium content of $37.08 \pm 0.05 \mathrm{mg} / 100 \mathrm{~g}$ was determined from $M$. oleifera seeds and $P$. africana seeds had $26.06 \pm 0.04 \mathrm{mg} / 100 \mathrm{~g}$ which can also be recommended when compare to maize with 0.93 content of potassium (Amata and Nwagu, 2013). The dietary allowance for potassium is 1875 to 5625 mg for adults (National Research Council, 1989). The seed could be recommended as source of dietary supplement for potassium.

The higher magnesium content was found to be $438.50 \pm 0.20 \mathrm{mg} / 100 \mathrm{~g}$ from $P$. africana, while $M$. oleifera content low magnesium with $218.20 \pm 0.10 \mathrm{mg} / 100 \mathrm{~g}$. Even though, it was found to below, yet it is high and recommended when compare to $0.13 \mathrm{~g}$ obtained from maize (Zea mays)(Amata and Nwagu, 2012). The human body contains $20-28 \mathrm{~g}$ of magnesium, more than half of which is stored in the bones. The element is an essential part of many enzyme systems and is also important in maintaining the electrical potential of nerve and muscle membranes, Agatemor and Mark, (2006).

The phosphorus content from the seeds based on the result was $468.00 \pm 1.00 \mathrm{mg} / 100 \mathrm{~g}$ from $M$. oleifera and $201.50 \pm 0.20 \mathrm{mg} / 100 \mathrm{~g}$ from $P$. africana. The dietary allowance for phosphorus is 800 $\mathrm{mg} / 100 \mathrm{~g}$ (National Research Council, 1989). Therefore, M. oleifera and P. africana seeds cannot be recommended as phosphorus supplements. Phosphorus a macronutrient comprises 22 percent of the total minerals of the body. Dietary deficiency of phosphorus is extremely unlikely as nearly all food content this mineral (Agatemor and Mark, 2006).

The Iron content in M. oleifera $(37.08 \pm 0.05 \mathrm{mg} / 100 \mathrm{~g})$ and $P$. africana seeds $(26.06 \pm 0.04 \mathrm{mg} / 100 \mathrm{~g})$ are low when compared to $50 \mathrm{mg} / 100 \mathrm{~g}$ obtained for Benni seeds (Dashak, and Fali, 1993). The dietary allowance for iron is $10 \mathrm{~g}$ for $70 \mathrm{~kg}$ (National Research Council, 1989). Therefore, M. oleifera and $P$. africana seeds could be recommended as a dietary supplement for people who need iron and those dwelling in the rural areas that live in poverty and even urban dwellers. This shows that these seeds are very rich in iron. Iron is very important for the formation of haemoglobin and normal functioning of the central nervous system (Vyas and Chandra, 1984).

The Iodine content of the selected seeds was evaluated with $M$. oleifera seed had low iodine content of $59.05 \pm 0.03 \mathrm{mg} / 100 \mathrm{~g}$ while $\mathrm{P}$. africana seed content $102.50 \pm 0.20 \mathrm{mg} / 100 \mathrm{~g}$. Thus these seeds can be recommended as a dietary supplement in the developing countries especially for the purpose of food security. 
The most abundant minerals among the mineral composition found in the study edible seeds were potassium $(502.00 \pm 1.00 \mathrm{mg} / 100 \mathrm{~g})$, calcium $(245.73 \pm 0.13 \mathrm{mg} / 100 \mathrm{~g})$, magnesium $(438.50 \pm 0.20$ $\mathrm{mg} / 100 \mathrm{~g})$, phosphorus $(468.00 \mathrm{mg} / 100 \mathrm{~g})$, Iodine $(102.50 \pm 0.20 \mathrm{mg} / 100 \mathrm{~g})$ and Iron $(37.08 \pm 0.05$ $\mathrm{mg} / 100 \mathrm{~g}$ ). The observation that Potassium is the most abundant mineral element is in accords with Olaofe and Sanni (1988) and Oshodi et al., (1999) which reported that potassium to be the most abundant mineral in Nigerian agricultural products. High amount of calcium, potassium and magnesium (as macro elements) may help to lower the blood pressure (Ranhotra et al., 1998). Several clinical studies have shown potassium, magnesium and calcium to be effective pressure lowering agents (Osborne et al., 1996), hence consumption of these seeds may help achieve this purpose.

\section{CONCLUSION}

M. oleifera and P. africana seeds are sources of mineral nutrients for human body as useful dietary supplements. These edible seeds could be good nutrient sources if integrated fully into human nutrition. People should be encouraged to plant and manage these plant species as cheap sources of minerals and vitamins. Some forest seeds have been proven to be edible, available, and affordable; and contain most of the nutritional requirements in large proportion. These seeds (fruits) are rich in minerals and vitamins, which could reduce the level of malnutrition in most developing countries of Africa. Therefore, study should be carryout to investigate the present of nitrite, total acidity and other anti-nutrients to make the seeds safe for human consumption.

\section{REFERENCES}

[1] Agatemor, C. and Mark, E. U. (2006): Nutritional Potential of the Nut of Tropical Almond (Terminalia Catappia L.); Pakistan Journal of Nutrition 5 (4): 334-336, 2006 ISSN 1680-5194

[2] Akpabio, U. D. (2012): Evaluation of proximate composition, mineral element and anti- nutrient in almond (Terminalia cattapa) seeds. Advances in Applied Science Research, 2012, 3 (4):2247-2252 ISSN: 09768610. CODEN (USA): AASRFC, Pelagia Research Library www.pelagiaresearchlibrary.

[3] Amata, I.A and Nwagu, K.M (2013): comparative evaluation of the nutrient profile of the seeds of four selected tropical plants and maize. International Journal of Applied Biology and Pharmaceutical Technology, Vol. 4: 1. ISSN: 0976-4550. Pp 200-204. www.ijabpt.com

[4] Anon (2009): www.wikipedia.Akee.html. 10/09/08.

[5] Association of Official Analytical Chemists (AOAC) (1990). Official method of analysis of the Association of official Analytical Chemist, 5th ad. AOAC Press, Arlington, Virginia, USA.

[6] AOAC (2005). Official method of analysis of the Association of official Analytical Chemist, 5th ad. AOAC Press, Arlington, Virginia, USA.

[7] Association of Official Analytical Chemists (AOAC) (2005): Official methods of analysis, 18th ed. Association of Official Analytical Chemists, Washington DC, 2005.

[8] Aremu, M.O., Olonisakin, A., Atolaye, B.O. and Ogbu, C.F. (2006) "Some Nutritional and Functional Studies of Prosopis africana". Electronic Journal of Environment, Agriculture and Food Chemistry Vol. 5, No.6, pp.1640-1648.

[9] Balogun , M.A. and Oyeyiola, G.P. (2012): Changes in the Nutrient Composition of Okpehe During Fermentation. Pakistan Journal of Nutrition 11 (3): 270-275, 2012 ISSN 1680-5194 () Asian Network for Scientific Information, 2012

[10] Dashak, D. A. and Fali, C. N. (1993): Food Chemistry, 47: 53-75.

[11] Felger, R.S (1979): ancient crops for the twenty-first century. In:Ritchie G.A, Gary A, eds. New agricultural crops. AAAS selected symposium 38 boulder, col, USA:

[12] Fleck, H., Introduction to nutrition 3rd Edn. New York, Macmillian, 1976.

[13] Folkard, G.K and Sutherland, J.P (1996): Moringa oleifera — a tree and a litany of potential. Agro forestry Today 8: 5-8.

[14] Lea, Michael (2010). Bioremediation of Turbid Surface Water Using Seed Extract fromMoringa oleiferaLam. (Drumstick) Tree. doi:10.1002/9780471729259.mc01g02s16.

[15] Lu, L and Olson, M (2001). Moringaceae. In: Flora of China, Volume 8: Brassicaceae through Saxifragaceae (eds Z-Y Wu and P Raven). Missouri Botanical Garden Press, St. Louis, Missouri, USA.

[16] National Research Council (1989): Food and Nutrition Board. Recommended Dietary Allowances. 8 th edition. National Academy of Science 20- 32. 
[17] Ogungbenle, H.N., Oshodi, A.A and Oladimeji, M.O., 2005, Chemical, Energy evaluation of some underutilized legume flours. Riv. Italia Sos. Grasse 82 (4) 204-208.

[18] Olaofe, O. and Sanni O. (1988): Mineral Contents of Agricultural products. Food Chem. 30, 73-77.

[19] Olaefe, J. O. (1987): Nigerian tress. Annual of Botany, 14: 159-161.

[20] Osborne, C.G., R.B. Mctyrc, J. Duek, K. Roche, R. Scheuplein, B. Silverstein, M.S. Winberg and A.A. Salkeld, (1996): Evidence for the relationship of calcium to blood pressure. Nutr. Rev., 54: 365-381.

[21] Oshodi, A.A., Ogungbenle, H.N., Oladimeji, M.O., (1999): Chemical composition, functional properties and nutritionally valuable minerals of benniseed, pearl millet, quinoa seed flour. International Journal of Food Science Nutrition. 50, 325 - 331.

[22] Ranhotra, G.S., J.A. Gelroth, S.O. Leinen, M.A. Vmas and K.J. Lorciz, (1998): Nutritional profile of some edible plants from Mexico. J. Food Comp. Anal., 11: 298-304.

[23] Scariano, J.K., E.A. Walter, R.H. Glew, B.W. Hollis, A. Henry, I. Ocheke and C.O. Isichei, (1995): Serum Levels of the Pyridinoline Crosslinked Carboxyterminal Telopeptides of Type 1 Collagen (ICTP) and Osteocalcin in Rachitin Children in Nigeria. Clin. Biochem., 28: 541- 545.

[24] Verdcourt, B (1985): A synopsis of the Moringaceae. Kew Bulletin 40: 1-23.

[25] viano J. Masotti V., Gaydou E.M, Bourreil PJL, Ghiglione, Giraud M. (1995): compositional characteristic of 10 wild plant legumes from Mediterranean French pastures. J Agric Food Chem 1995; 43:680

[26] Von Maydell H.J.(1986):Trees \& Shrubs of the Sahel, their Characteristics \& uses.Deutsche Geselischaft (GST). Germany, pp334-337.

[27] Vyas, D. and R.K. Chandra, 1984. Iron nutrition in infancy and childhood. Nestle Nutrition Edn., pp: 21-25. Zewel, M.B., 1977. Dietary pattern and hypertension. DASH Stud. Nutr. Rev., 55: 303-305.

Citation: Abubakar, E.M and Abdulhamis, B., "The Nutritional Contributions of Moringa oleifera (Lam) and Prosopis africana (Guill \& Perr) Taub Seeds for Sustainable Diets to Food Security", International Journal of Forestry and Horticulture (IJFH), vol. 3, no. 3, p. 6, 2017. http:// dx.doi. org/ 10.20431/24549487.0303004

Copyright: (ㅇ) 2017 Authors. This is an open-access article distributed under the terms of the Creative Commons Attribution License, which permits unrestricted use, distribution, and reproduction in any medium, provided the original author and source are credited. 